\title{
Innovation and competence building in the Brazilian Biopharmaceutical Industry
}

\section{Paper submitted to the $1^{\text {st }}$ ENEI}

\author{
Nathalia Alves', Marco Vargas ${ }^{2}$, Jorge Britto
}

\begin{abstract}
This paper seeks to address the competence building process and the promotion of innovation in the Brazilian Biopharmaceutical Industry. In doing so, the paper focuses in two major issues. The first regards a preliminary assessment of the scientific and technological competencies of the Brazilian academic institutions with regard to crucial areas to the consolidation of the biopharmaceutical research, development and innovation (RD\&I) chain in the country. The second issue is intended to explore university-industry relationships regarding technology transfers and knowledge flows. The analysis is based upon data obtained from the Brazilian National Council for Scientific and Technological Development Research Groups directory $(\mathrm{CNPq})$ and from the $\mathrm{CNPq}$ Investment Panel database. Moreover, in order to assess Brazilian insertion in international knowledge flows, a third data source concerning Brazilian scientific production indexed internationally by area of knowledge was gathered from SCImago Journal \& Country Rank.
\end{abstract}

\section{Resumo}

Este artigo procura abordar o processo de criação de competências e a promoção da inovação na indústria biofarmacêutica brasileira. O estudo centra-se em duas questões principais. A primeira consiste em uma avaliação preliminar das competências científicas e tecnológicas das instituições acadêmicas brasileiras em relação a áreas cruciais para a consolidação da cadeia de $\mathrm{P} \& \mathrm{D}$ da indústria biofarmacêutica no país. A segunda questão destina-se a explorar as relações universidade-empresa em termos de transferências de tecnologia e fluxos de conhecimento. A análise é baseada em dados extraídos do Diretório dos Grupos de Pesquisa do Conselho Nacional de Desenvolvimento Científico e Tecnológico (CNPq) e do Painel de Investimentos do CNPq. Além disso, a fim de avaliar a inserção brasileira em fluxos internacionais de conhecimento, uma terceira fonte de dados sobre a produção científica brasileira indexada internacionalmente por área de conhecimento foi recolhida a partir SCImago Journal \& Country Rank.

Key Words: Scientific and technological capabilities; Biopharmaceuticals; Relationships between research groups and industrial sector.

JEL Classification Numbers L65, O15, O30.

ABEIN Classification Area 5

\section{Introduction}

\footnotetext{
${ }^{1}$ Master degree student, PPGE-UFF

${ }^{2}$ Full Professor of the Department of Economics - Federal Fluminense University - UFF

${ }^{3}$ Full Professor of the Department of Economics - Federal Fluminense University - UFF
} 
The pursuit of competences on new platforms of biotechnology in human health is crucial for enabling the domestic production of biopharmaceuticals. In Brazil, the existence of a health care model guided by universal access, associated with changes in the demographic and epidemiological patterns in the country, has considerably increased the demand for health services and pushed public spending on biopharmaceuticals supplied by the Brazilian Unified Health System (SUS) during the past decade. The consolidation of local production of generic drugs in the last decade has significantly increased the share of national firms in the Brazilian pharmaceutical market and it represented an important turning point for this industry's technological learning trajectories. Despite the advances during the 2000s, the analysis of the Brazilian pharmaceutical industry still shows important structural bottlenecks particularly regarding the adoption of biotechnology in drug development.

These bottlenecks reveal, on the one hand, the high vulnerability of the Brazilian National Health System that is increasingly dependent on biopharmaceuticals imports. In 2012, the purchase of drugs and medicines by the Ministry of Health, to the so-called "specialized component" of the pharmaceutical assistance program (mostly comprised of biopharmaceuticals) represented about $5 \%$ of the volume in acquired drug units and more than $40 \%$ of the value of acquisitions in Brazilian reais. Likewise, eight out of the 10 high-priced drugs imported to Brazil are biopharmaceuticals. On the other hand, aside from its importance as a structural element of the Health Industrial Complex and of the Welfare State, biopharmaceutical industry also plays a leading role in the national system of innovation in health as a research-intensive, knowledge-based industry. However, the productive base of Brazil's biopharmaceutical innovation system is extremely fragile, jeopardizing the production of biological drugs and the country's competitive insertion in the global biopharmaceutical industry. This scenario points to the need of strengthening the competence building processes in new technological platforms of biotechnology in human health in order to effectively enable the domestic production of biopharmaceuticals in Brazil ${ }^{4}$.

The scientific and technological infrastructure is a critical element of the National Innovation System in Health, and basis for the development of pharmaceuticals and biotechnology-based industry. Brazil has a wide range of institutions with consolidated research groups in biology and health sciences. The growing participation of the country in relevant scientific production in terms of international publications reinforce the importance of the scientific infrastructure development and strengthening. However, it appears that this infrastructure is still fragile and that progress in terms of building new capabilities in RD \& I are still limited. ${ }^{5}$

A critical issue for the Brazilian insertion into new strategic technology platforms in biopharmaceuticals refers to the mismatch between the degree of scientific training and the limited current capacity of existing production base of innovation in biopharmaceuticals. Thus, it appears that the main bottleneck concerns the relationship between the production of knowledge in universities and innovation in the productive sector. Another critical issue concerns the recent decrease in research support expenditures due to changes in Brazilian general economic environment and the signalized reverse in public policy directions concerning the promotion of scientific and technological infrastructure and innovation incentives. The potential negative implications of the environmental change to the Brazilian biopharmaceutical competences are still uncertain.

The paper focuses in two major issues. The first regards a preliminary assessment of the scientific and technological competencies of Brazilian academic institutions with regard to crucial areas of knowledge to consolidate the biopharmaceutical RD\&I chain in the country. The second issue is intended to explore university-industry relationships regarding technology transfers and knowledge flows from the academic sphere to the productive sector in order to foster innovation in Biopharmaceuticals. The analysis presented in this paper is based upon data obtained from the Brazilian National Council for Scientific and Technological Development Research Groups directory (CNPq). The CNPq database contains different information such as the number of the research groups, university or college staff integrated to the group, educational levels and aspects of university-industry relationships. The paper also presents data from the $\mathrm{CNPq}$ Investment Panel database, which consolidates expenditures data on scholarships stipends and

\footnotetext{
${ }^{4}$ Acoording to ABDI (2013) and Vargas et al (2013).

${ }^{5}$ See Gelijns, Rosenberg (1995); Guimarães (2011) and Britto et al (2012).
} 
research support from year 2001 to year 2015. The data can be used to capture possible impacts of changes in general economic environment on the competence building process in Biopharmaceuticals. Finally, in order to assess Brazilian insertion in international knowledge flows, a third data source concerning Brazilian scientific production indexed internationally by area of knowledge was gathered from SCImago Journal \& Country Rank.

The paper is organized as follows. Next section provides a brief overview on the theoretical basis that support the analysis held in the study. The third section presents the methodological aspects of the analysis conducted. The fourth section focuses on the Brazilian scientific and technological infrastructure regarding academic institutions. The fifth section concerns university-industry research collaboration during the past decade in knowledge areas related to biopharmaceuticals in Brazil. The sixth section presents the assessment held on the CNPq Investment panel. The last two sections provide main findings and final remarks of the study.

\section{Theoretical Basis}

The emergence of modern Biotechnology between the decades 1970 and 1980 represented a radical change in the knowledge base that supported search processes for new compounds and development of therapeutic drugs in the pharmaceutical industry. The technological paradigm breakdown conducted by the biotechnology revolution opened new innovation avenues for drug developments, impacting all stages of the RD \& I chain in the pharmaceutical industry. The technological shock was accompanied by institutional changes, shifts in demand for medicines due to national health policies, and increases in public investments on health sciences. The combination of these factors impacted all stages of the biopharmaceutical value chain and led to profound changes in the organization of firms and the interactions between the actors of pharmaceutical and biopharmaceutical sectoral system of innovation in the world (Mckelvey; Orsenigo; 2001. Dosi; Mazzucato, 2006).

The biopharmaceutical sector is defined as a science based industry, thus innovation is driven by joint advances in basic and applied research on life and health sciences (Dosi; Mazzucato, 2006). Science based firms are those found in sectors whose sources of technology are research and development activities conducted in corporate labs and based on the academic advances (Pavitt, 1984). Fonseca (2009) argues that scientific and technological infrastructure developments and access to external knowledge sources are critical to developing new marketable products in pharmaceutical and biotechnological industry. Science based industries are usually marked by innovation processes highly intensive in the research phase (other than in development or production phases), and by high and persistent technological opportunities and interdisciplinary bodies of knowledge (Coriat et al, 2003).

Eliasson and Eliasson (1996) point to the need of building bridges and establishing communication channels between academic inventions and possible commercial applications to enable disruptive innovations. The bridges were supposed to be built through interactions among academic researchers and the commercial experience of corporate labs scientists, of entrepreneurs and of venture capitalists. The biotechnology industry is understood as being equivalent to a building block of knowledge pieces and technological tools that coevolve in time, as an inherently interdisciplinary activity. Thus, inventions and innovations are thought to arise from combinations of scientific knowledge pieces in different academic areas (such as general biology, molecular biology and physiology) with commercial applications, marketing knowledge and production skills (typical character of corporative labs and productive sector). The Eliasson and Eliasson (1996) approach emphasizes: (1) the importance of human sources skills and competence building as a determinant for innovations in the pharmaceutical and biopharmaceutical industry; (2) the need of a sufficiently diverse environment in scientific and technological infrastructure; (3) exploitation of synergy effects between combining knowledge fields and technological tools in order to foster new marketable drugs developments (Eliasson; Eliasson, 1996; Fonseca, 2009).

Biotechnology originated in academia and therefore corresponds to the ideal picture of a sciencebased industry pushed in academic literature (...) New discoveries of products are almost always the result of a combination of different clusters of scientific knowhow; for instance, in chemistry, in molecular biology, cell biology, physiology and laboratory technology. As a consequence, innovations and industrial applications predominantly occur in competence blocs where a 
sufficiently diverse environment exists and where new and often not foreseen synergy effects can be captured (Eliasson; Eliasson, 1996:7-8)

Academic literature highlights the importance of universities and research institutes according to three main functions: 1) Teaching and human resource training in research methods; 2) Research and expansion of knowledge base; and 3) Entrepreneurial role of universities (Sampat; Mowery, 2005. Etzkowitz; Leydesdorff, 2000. Paranhos, 2012).

Within National Systems of Innovation approach, the classic functions of teaching and research are marked as universities main missions. The first function is directly related to the human resources training in research methods. Human capital is considered a key factor for succeeding in innovative efforts within private companies, so that proper training is critical to innovation. Hiring university graduates to industry labor posts is considered a form of indirect knowledge diffusion from academia to industry (Sampat; Mowery, 2005). Gibbons e Johnston (1974), while analyzing possible contributions from science to technology, highlighted the importance of the "problem-solver" figure as a professional well trained in research methods and scientific experiments to stimulate the use of personal and external sources of knowledge, fostering innovation processes.

The second university mission is related to the base of knowledge replacements. The direct contribution of academic research results in increasing the pool of knowledge and expanding technological opportunities are likely to happen mostly in science based industries (Klevorick et al.1995). In science and technology intensive sectors, mutually beneficial dynamic connections may be established between companies and universities to create, develop and diffuse inventions and innovations (Sampat; Mowery, 2005).

A third university mission is well contemplated by the triple helix approach that emphasizes the entrepreneurial role of universities in knowledge transfers and fostering innovations by: 1) patenting and licensing knowledge to the productive sector, 2) providing consulting services and stablishing partnerships with industry, 3) promoting academic spin-offs (defined as new companies created to explore knowledge pieces created in the academia in Shane (2004)). The innovation system is understood as an interconnected structure of three interacting dynamic spheres: university, industry and the government. According to this framework, universities emerge as a main actor of radical innovation, highlighting the incremental nature of the innovations developed within individual companies. (Etzkowitz; Leydesdorff, 2000. Sampat; Mowery, 2005).

Additionally, Gibbons and Johnston (1974) indicate the existence of four possible types of contributions from science to technology: skilled labor training; direct application of scientific research results; technology developments and "problems solving" based on previous basic research results; and discoveries out of curiosity led research. Pavitt (1990) highlights the importance of accumulated improvements in continuous processes to technology, including competence building processes, routines and methods based on the problem-solving practice. Thus, technological development often involves a combination of different sources of knowledge managed by some degree of tacit knowledge in terms of skills and know-how. Price (1965) points that interactions between science and technology take place mainly through training processes and academic education, when direct personal contact between scientists and technologists is stablished. While Henderson et al. (1998), understands technological innovation as an evolutionary process of continuous applications of basic and applied results.

The transfer of academic knowledge to industry involved in the case of biotechnology, the creation of new biotech companies instead of direct relationships between large pharmaceutical companies and universities (Mckelvey; Orsenigo, 2001). Shane (2004) argues that few technologies are conducive to generate spin-offs and most academic inventions are licensed directly from academia to incumbent firms. In biotechnology, some features related to health and life sciences, such as: the long term of development processes, academic expertise, quality and efficiency importance, patents effective protection, discrete nature of inventions and possible direct commercial applications of research results are some of the features that have favored the emergence of spin-offs. As Mazzucato (2011) marks out: "most of the new biotech companies were new spin-offs from university labs with heavy state funding" (Mazzucato, 2011: 43).

Despite the high entry of new biotechnology companies in the pharmaceutical industry, the entrants have not become integrated pharmaceutical producers nor were sufficient to reduce the market 
share of large pharmaceutical firms that kept its importance in the innovation systems. The arising costs of RD\&I chain, the scale and scope economies in production, the distribution and marketing requirements, the long and costly clinical trials and drug approval regulatory requirements are some of the reasons to the emerge of two contrasting phenomena in the pharmaceutical industry: 1) The emerge of collaborative relationships based on complemental assets between pharmaceutical companies, universities and biotechnology companies; and 2) The process of merges and acquisitions (Arora; Gambardella, 1995. Gravaglia et al, 2006).

The literature indicates the emergence of a new organizational form within the Pharmaceutical Innovation System guided by the emergence of a dense network of collaborations and strategic alliances between heterogeneous organizations. In the scheme proposed by Arora and Gambardella (1995) three groups of agents contribute through cooperation and systematic interactions: universities, biotechnology companies and the established pharmaceutical companies. Promoting, as a result, the transfer of the innovation process from the individual organizations to the cooperative network (Arora; Gambardella, 1995).

In Brazil, according to Brazilian Association for Industrial Development (ABDI $\left.{ }^{6}, 2013\right)$, the biopharmaceutical industry structure involves the presence of three key actors: universities and research institutions, public laboratories, national and international pharmaceutical companies, and biotechnology firms. Generic drugs local production consolidation in the last decade has significantly increased the share of national firms in the domestic pharmaceutical market, and represented an important turning point for the technological learning trajectories of national pharmaceutical laboratories. Brazilian pharmaceutical groups have assimilated the strategy of expanding markets through the production of generic drugs and the entry into the biopharmaceuticals production is therefore an important window of opportunity for the sustainable growth and consolidation of the Brazilian pharmaceutical industry (Vargas et al, 2012. Vargas; Britto, 2015).

Bianchi (2012), Biominas and PWC (2011), and CEBRAP and BrBiotec (2011) pointed the existence of several biotechnology companies in Brazil that are aligned with the science based business model. The studies indicate that the Brazilian Biotechnology companies are mostly young and small companies, backed by national capital and by financial support from government agencies. Interactions with universities and research institutes are marked to be an important feature to biotech company's emergence in Brazil. According to CEBRAP and BrBiotec (2011), 95\% of the biotechnology companies in Brazil hold relationships with academic and research institutions.

The Brazilian pharmaceutical industry is characterized by low concentrations patterns and by the coexistence of several national pharmaceutical enterprises, big pharma companies stablished in the country and the emergence of the new biotech companies. While the national pharmaceuticals enterprises whose competencies were fostered based on the generic production strategy have adopted a similar strategy toward the biopharmaceuticals products, based on attempts to product biosimilar and bioequivalent drugs highly anchored on it productive competences and incremental innovations skills; the new biotech companies are more focused on new products developments and disruptive innovations based on academic knowledge and research results (Gomes, 2014).

Research institutions and public production laboratories are also key players in the Brazilian pharmaceutical industry. It is important to remark the importance of public laboratories, such as Butatan and Bio-Manguinhos institutes, in the Brazilian effort to consolidate production and innovation competences in biopharmaceuticals. Public pharmaceutical laboratories have a strategic importance for the country as respond by producing $80 \%$ of vaccines and $30 \%$ of the drugs used in SUS, however, besides having various legal models, the official laboratories have significant differences in terms of productive infrastructure and technology (Vargas et al, 2013).

The initiatives for biopharmaceutical production in Brazil have been encouraged by public policies, considering the strategic importance of health innovation in promoting both sustanaible gowth and technology catching-up. It is important to mark out that the industrial policy mechanisms and science, technology and innovation incentives scopes are linked not only to national pharmaceutical companies

\footnotetext{
${ }^{6}$ From Brazilian anachronism: Associação Brasileira de Desenvolvimento Industrial (ABDI).
} 
innovative efforts, but also to brooding and densification of the biopharmaceutical RD\&I chain in the country (Vargas et al, 2013). Bianchi (2012) points to a great effort by the Brazilian government to promote and consolidate the development of scientific and technological infrastructure dedicated to the development of biotechnology in the country in the past two decades, as shown in table 1 below.

\begin{tabular}{|c|c|}
\hline Policy & Objectives \\
\hline $\begin{array}{l}\text { Industrial, Technology and Foreign } \\
\text { Trade Policy Program ( PITCE) } \\
2004\end{array}$ & $\begin{array}{l}\text { - Points innovation as central axis of productive policy and foreign trade, focusing } \\
\text { biotechnology and the health industrial complex as priority areas - } \\
\text { Create a space for the definition of biotechnology development strategy: } \\
\text { "Biotechnology Forum" }\end{array}$ \\
\hline $\begin{array}{l}\text { Biotechnology Development Policy } \\
\text { (PDBIO) } \\
2007\end{array}$ & $\begin{array}{l}\text { - Incorporates general criteria defined in PITCE } \\
\text { - Creates the Biotechnology Committee as governance instance of the development } \\
\text { of biotechnology policy support } \\
\text { Defines specific objectives for the development of biotechnology in four areas and } \\
\text { sectors: Industry, Environment, Agriculture and Health. } \\
\text { - Sets horizontal actions: investments, infrastructure, human resources training and } \\
\text { improvement of the regulatory framework. }\end{array}$ \\
\hline $\begin{array}{l}\text { Action Plan } 2007-2010 \text { of Science, } \\
\text { Technology and Innovation for } \\
\text { Development (PACTI) }\end{array}$ & $\begin{array}{l}\text { - Keeps the definition of biotechnology as an area "carrier of the future" adopted in } \\
\text { PITCE } \\
\text { - Adopt biotech areas defined in PDBIO and sets specific proposals for the } \\
\text { development of programs and products in the areas established by PDBIO. } \\
\text { - Sets the budget forecast of MCT for Biotechnology 2008-2010 }\end{array}$ \\
\hline $\begin{array}{l}\text { Productive Development Policy } \\
\text { (PDP) } \\
2008\end{array}$ & $\begin{array}{l}\text { - Adopts the goals and targets set in the Action Plan 2007-2010 to give } \\
\text { competitiveness to biotechnology. } \\
\text { - Adopts the strategic areas of definitions set out in PDBIO } \\
\text { - } \quad \text { Adds new targets for the development of biotechnology in the country }\end{array}$ \\
\hline $\begin{array}{l}\text { National Strategy for Science, } \\
\text { technology and Innovation } \\
(\text { ENCTI) 2011-2014 }\end{array}$ & $\begin{array}{l}\text { - } \quad \text { Keeps the definition of biotechnology as a strategic area for the country } \\
\text { Binds development strategies in biotechnology with national development goals: } \\
\text { health, food and biodiversity. } \\
\text { It sets out five goals (strategies) from which you can appreciate the continuity with } \\
\text { previous policies. }\end{array}$ \\
\hline
\end{tabular}

Source: Bianchi (2012).

However, those policies aimed at strengthening the biotechnology applied to health (as the biotechnology in general), do not necessarily promote a coherent construction and link the creation of scientific capabilities with the development of industrial capacity and attention to the health needs of the population. The systemic perspective of the industrial and the ST\&I policies in the health sector has also allowed the adoption of a wide range of instruments to support the development of biopharmaceutical industry in Brazil. As emphasized by Vargas et al (2013), such instruments have involved not only direct promotion to R\&D activities in national companies, but also other forms of support for innovation, such as the review of the regulatory framework and the use of government purchasing power

In this sense, it is worth mentioning the Partnerships for Productive Development (PDP), a major governmental program coordinated by the Ministry of Health that was launched in 2009 and has become one of the backbones of the articulation between the Health Policy and Innovation Policy for the Brazilian Health Economic and Industrial Complex (HEIC) ${ }^{7}$ (Gadelha et al 2012). This program aims at promoting technology transfer processes between public and private pharmaceutical laboratories and have a strong focus in the production of biopharmaceuticals that represent a strategic niche for the National Health System and the public pharmaceutical laboratories. The Partnership Program for Productive Development (PDPs) was created by the Ministry of Health as part of a strategic effort aimed at fostering the developing of the Health Economic and Industrial Complex (HEIC) and promoting the production and access to essential drugs in the National Health System. This program is strongly based in the use of government purchasing power as an industrial policy instrument and represents a central element in the construction of systemic innovation policies in the health sector.

\footnotetext{
${ }^{7}$ In the field of health policy, with the resumption of an agenda for health in the 2000s, the concept of Health Economic and Industrial Complex (HEIC) began to be systematic mentioned in numerous policy documents that have been incorporated into the National Health Plan.
} 
Despite the presence of a National Biotechnology Committee with the aim to coordinate the implementation of the Government's biotechnology policies, it is hardly to identify a completely wellstructured national innovation strategy for biotechnology activities in Brazil. However, it is possible to identify a broad set of policy initiatives to promote innovation in biopharmaceutical products, combining supply and demand side measures to encourage innovation (GEORGHIOU, 2006). Supply-side policies seek to ensure that innovative agents have adequate resources, such as human, natural, knowledge, financial infrastructural etc. Those policies include subsidies or tax breaks, as well as "softer" supply-side actions, such as enhancing capacity to adapt and absorb exogenous innovations. At the supply-side, Innovation is also affected by even more foundational policies, such as those on education and infrastructure. Contrasting to these orientations, demand-side policies seek to provide sufficient incentives to innovative agents, including policies that structure the market or the rewards flowing from it, affecting not only the quantity but mainly the quality of demand. Demand-side interventions can be more direct such as the use of public sector procurement to drive demand for biopharmaceutical products - or less direct - including attempts to shape consumption via standards, helping articulation among consumers and potential innovators, and introducing sectoral regulations that require innovative responses.

According to the study "Building the Bioeconomy Examining National Biotechnology Industry Development Strategies" (2014) there are a set of enabling factors that together create an environment conducive to biotech innovation, ranging from the institutional and eco-system level (such as levels of tertiary education and IP environment) to the more biotech specific character, trying to affect what type of biomedical and biotech R\&D infrastructure does a country have in place and the availability of technology transfer laws and mechanisms. Among these factors, it is possible to mention: i) the availability of skilled and technically trained human capital; ii) the presence of a R\&D infrastructure to foster innovation in dynamic areas of pharmaceutical biotechnology; iii) a regulatory environment able to establish adequate levels of quality and safety for biopharmaceuticals products; iv) the mobilization of technology transfer mechanisms and private - partnerships articulating research institution and private firms, in order to provide technical services and to develop commercially available technologies; v) the mobilization of different market and commercial incentives such as tax incentives, general support for basic research and credits for investments in R\&D infrastructure; vi) the mobilization of the public procurement and the pricing and reimbursement systems for medicines and health technologies to induce the development and diffusion of innovative solutions; vii) regulatory issues concerning biologics and biosimilar products. The evidences about the Brazilian experience discussed below denote that these different instruments have been mobilized and combined in pragmatic way to foster the development of innovations in the biopharmaceutical sector.

Concerning the competence building process required to consolidate the biopharmaceuticals production in the, Brazil seems to have some advantages concerning the scientific and technological infrastructure in research and knowledge production. Brazil has a wide range of academic institutions with consolidated research groups in biology and health sciences. The current stage of development of biotechnology in Brazil is largely due to the human resource training policy promoted by institutions such as the Higher Education Personnel Improvement Coordinator (Capes) and CNPq. The growing participation of the country in relevant scientific production in terms of international publications reinforce the importance of the scientific infrastructure development and strengthening. However, it appears that this infrastructure is still fragile and that progress in terms of building new capabilities in RD \& I are still limited (BRITTO et al, 2012; VARGAS.BRITTO, 2014).

\section{Methodological Aspects}

This section examines recent developments in biopharmaceuticals-related scientific competences and university-industry research collaboration improvements in Brazil. The analysis presented in the next sections are based upon data obtained from the Brazilian National Council for Scientific and Technological Development $(\mathrm{CNPq})$ concerning scientific and technological infrastructure and the relationship between research groups and the industrial sector. The National Research Group directory statistics are available according to data collection in biannual censuses from the year 2000 to the year 2010, in addition to a census held in the year 2014. Thirteen knowledge fields closely related to the biopharmaceutical industrial R\&D chain activities were selected: Biochemistry, Biomedical engineering, 
Biophysics, General biology, Genetics, Immunology, Medicine, Microbiology, Morphology, Parasitology, Pharmacology, Pharmacy and Physiology, in accordance with the methodology adopted by the authors in previous studies concerning scientific and technological competencies in health ${ }^{8}$.

Additional data was obtained from the CNPq Investment Panel database, called Payment Data Mart, which consolidates expenditures data on scholarships stipends and research support from year 2001 to year 2015. The information available covers the total value invested per year for eighteen areas selected: Biochemistry, Biomedical engineering, Biophysics, General biology, Genetics, Immunology, Medicine, Microbiology, Morphology, Parasitology, Pharmacology, Pharmacy, Physiology, Biotechnology; biomedicine, technological innovation and development in biology, technology and innovation and medical and health technologies. Besides the thirteen critical areas selected for the $\mathrm{CNPq}$ directory analysis, five additional areas considered closely related to the biopharmaceutical industry were added to the analysis due to mismatches in the two separates databases.

In order to assess Brazilian insertion in the international scenario, a third data source concerning Brazilian scientific production indexed internationally by area of knowledge was gathered from SCImago Journal \& Country Rank, a specialized portal in scientific bibliometric indicators based on Elsevier Scopus ${ }^{\circledR}$ database. The data collected for the period between the years 2000 and 2014 considered the following research areas: i) biochemistry, genetics and molecular biology; ii) Immunology and Microbiology; iv) Medicine; viii) Pharmacology, toxicology and pharmaceutical. The knowledge areas selection reflects an attempt to match the thirteen critical areas selected in the CNPq directory assessment, considered the differences in the three different sources of data.

\section{Scientific and technological research competencies on biopharmaceuticals in Brazil.}

The data collected from the CNPq directory from 2000 to 2014, according to the critical knowledge areas selection display a significant growth in the number of research groups, research lines and researchers dedicated to knowledge fields closely related to the biopharmaceuticals industry. The average growth of $\mathrm{CNPq}$ total research groups surpasses the growth in selected areas research groups, reflecting a loss of relative share in selected areas compared to the entire Brazilian scientific production capacity along the years 2000 and 2014. The same occurrence can be perceived for research lines and researchers. The knowledge areas highlighted as more significant in terms of 2000-2014 growth and relative share in selected areas were: Biochemistry, Genetics, Medicine, Microbiology and Pharmacy.

Table 2 shows that the number of research groups in selected areas grew 124\% for the 2000-2014 period of time, as well as the number of research lines $(206 \%)$ and researchers $(274 \%)$. Concerning the total growth in research groups, a greater attention must be paid to the areas: Pharmacy $(351 \%)$ and Biomedical engineering (195\%).The thirteen selected areas represented an average of $16 \%$ of total research groups in the $\mathrm{CNPq}$ directory during the period considered. The more relevant areas in $\mathrm{CNPq}$ relative share were: medicine, Biochemistry, Genetics, Pharmacy and Microbiology, whose together represent $11.4 \%$ of the $16 \%$ share verified.

The data also points to an average growth of selected areas that is overlapped by the average growth of entire set of $\mathrm{CNPq}$ areas. As a result, the share of selected areas research groups in comparison to $\mathrm{CNPq}$ is decreasing over the years, going from $18 \%$ in the 2000 to $13 \%$ in 2014 . The average loss in $\mathrm{CNPq}$ relative share was of $-4.8 \%$ for research groups, $-2.8 \%$ for research lines and $-2.6 \%$ for researchers. The subject areas more influenced by the decrease in research groups' relative importance were Biomedical engineering, Physiology, Biochemistry and Morphology. Except for Genetics and General biology that experienced positive variations in CNPQ relative share, all the others critical areas displayed negative variations index. The critical areas loss in relative share reflects the highly comparative increase in knowledge areas such as: Administration, Arts, Communication, Industrial Design, Law, Physical Education, among others.

\footnotetext{
${ }^{8}$ For a comprehensive discussion on the methodological issues, please see Britto et al, 2012, Vargas, and Britto, 2014.
} 


\begin{tabular}{|c|c|c|c|c|c|c|c|c|c|c|}
\hline Subject areas & 2000 & 2002 & 2006 & 2010 & 2014 & $\begin{array}{l}\text { Average } \\
\text { share in } \\
\text { selected } \\
\text { areas \% }\end{array}$ & $\begin{array}{r}\text { Average } \\
\text { share in } \\
\text { CNPq } \\
\text { areas \% }\end{array}$ & $\begin{array}{r}\text { Average } \\
\text { share in } \\
\text { CNPq } \\
\text { variation } \\
2000- \\
2014 \%\end{array}$ & $\begin{array}{r}\text { Average } \\
\text { growth } \\
2000- \\
2014 \%\end{array}$ & $\begin{array}{r}\text { Total } \\
\text { growth } \\
2000- \\
2014 \%\end{array}$ \\
\hline Biochemistry & 210 & 274 & 330 & 381 & 475 & $9.8 \%$ & $1.6 \%$ & $-8.3 \%$ & $15 \%$ & $126 \%$ \\
\hline Biomedical engineering & 40 & 53 & 71 & 84 & 118 & $2.1 \%$ & $0.3 \%$ & $-14.1 \%$ & $22 \%$ & $195 \%$ \\
\hline Biophysics & 46 & 60 & 57 & 74 & 80 & $1.9 \%$ & $0.3 \%$ & $-4.6 \%$ & $10 \%$ & $74 \%$ \\
\hline General biology & 49 & 58 & 54 & 33 & 52 & $1.6 \%$ & $0.3 \%$ & $0.2 \%$ & $4 \%$ & $6 \%$ \\
\hline Genetics & 189 & 249 & 313 & 376 & 417 & $9.1 \%$ & $1.5 \%$ & $7.5 \%$ & $14 \%$ & $121 \%$ \\
\hline Immunology & 101 & 119 & 151 & 163 & 186 & $4.4 \%$ & $0.7 \%$ & $-5.3 \%$ & $11 \%$ & $84 \%$ \\
\hline Medicine & 737 & 925 & 1.276 & 1.437 & 1.625 & $36.2 \%$ & $5.8 \%$ & $-4.6 \%$ & $15 \%$ & $120 \%$ \\
\hline Microbiology & 179 & 220 & 269 & 300 & 365 & $7.9 \%$ & $1.3 \%$ & $-4.9 \%$ & $13 \%$ & $104 \%$ \\
\hline Morphology & 109 & 130 & 148 & 200 & 226 & $4.7 \%$ & $0.8 \%$ & $-7.7 \%$ & $13 \%$ & $107 \%$ \\
\hline Parasitology & 115 & 133 & 157 & 171 & 193 & $4.6 \%$ & $0.7 \%$ & $-4.9 \%$ & $9 \%$ & $68 \%$ \\
\hline Pharmacology & 107 & 124 & 151 & 178 & 231 & $4.6 \%$ & $0.7 \%$ & $-6.2 \%$ & $14 \%$ & $116 \%$ \\
\hline Pharmacy & 103 & 171 & 289 & 385 & 465 & $8.0 \%$ & $1.3 \%$ & $-5.8 \%$ & $30 \%$ & $351 \%$ \\
\hline Physiology & 110 & 136 & 163 & 196 & 250 & $5.0 \%$ & $0.8 \%$ & $-9.2 \%$ & $15 \%$ & $127 \%$ \\
\hline $\begin{array}{l}\text { Research groups - selected } \\
\text { areas }\end{array}$ & 2095 & 2652 & 3429 & 3978 & 4683 & $100 \%$ & $16 \%$ & $-48 \%$ & $15 \%$ & $124 \%$ \\
\hline Research groups - CNPq & 11.760 & 15.158 & 21.024 & 27.523 & 35.424 & & $100 \%$ & & $21 \%$ & $201 \%$ \\
\hline Selected areas/CNPq \% & $18 \%$ & $17 \%$ & $16 \%$ & $14 \%$ & $13 \%$ & & & & & \\
\hline Research lines - selected areas & 6883 & 9407 & 13775 & 17361 & 21043 & & $17 \%$ & $-2.8 \%$ & $21 \%$ & $206 \%$ \\
\hline Research lines - CNPq & 38.126 & 50.473 & 76.719 & 106.715 & 139154 & & $100 \%$ & & $24 \%$ & $265 \%$ \\
\hline Selected areas/CNPq areas $\%$ & $18 \%$ & $19 \%$ & $18 \%$ & $16 \%$ & $15 \%$ & & & & & \\
\hline Researchers - selected areas & 10357 & 12985 & 21086 & 28648 & 38707 & & $15 \%$ & $-2.6 \%$ & $25 \%$ & $274 \%$ \\
\hline Researchers - CNPq & 66.804 & 83.850 & 138.278 & 205.445 & 293991 & & $100 \%$ & & $28 \%$ & $340 \%$ \\
\hline Selected areas/CNPq \% & $16 \%$ & $15 \%$ & $15 \%$ & $14 \%$ & $13 \%$ & & & & & \\
\hline
\end{tabular}

Source: Elaborated by the authors based on the data published by CNPq directory (2016)

Despite the decrease in CNPq relative share, Table 3 points to an improving composition of research groups human resources considering the level of education achieved by researchers engaged in selected areas. The research groups are majorly composed by highly specialized professionals. Among $92 \%$ of the total number of individuals allocated in critical areas were granted MSc or PhD degrees, an average rate higher than the $90 \%$ associated to CNPQ all areas for $2000-2010^{9}$ period. The composition percentages of doctor degrees increased from 69\% in the year 2000 to $81 \%$ in 2010 while MSc degrees share decreased from $20 \%$ of 2010 to $13 \%$ in 2014 . Thus, data points to a substitution effect favoring the higher specialized professionals. It is important to remark that the substitution effect do not address the entire composition variation for there has been an increase from $89 \%$ to $94 \%$ in the $\mathrm{MSc}$ and $\mathrm{PhDs}$ degrees researcher in selected areas 2000 to 2010 .

\begin{tabular}{|c|c|c|c|c|c|c|}
\hline \multirow[b]{2}{*}{ Year } & \multirow[b]{2}{*}{ Total number of researchers } & \multicolumn{5}{|c|}{ Education degrees \% } \\
\hline & & Bachelor & Graduate specialization & MSc & $\mathrm{PhD}$ & Uninformed \\
\hline 2000 & 9021 & $4 \%$ & $7 \%$ & $20 \%$ & $69 \%$ & $0 \%$ \\
\hline 2002 & 10971 & $3 \%$ & $4 \%$ & $16 \%$ & $75 \%$ & $2 \%$ \\
\hline 2004 & 15300 & $3 \%$ & $5 \%$ & $15 \%$ & $76 \%$ & $1 \%$ \\
\hline 2006 & 17531 & $2 \%$ & $5 \%$ & $14 \%$ & $78 \%$ & $1 \%$ \\
\hline 2008 & 19928 & $2 \%$ & $5 \%$ & $13 \%$ & $80 \%$ & $0 \%$ \\
\hline 2010 & 23560 & $2 \%$ & $4 \%$ & $13 \%$ & $81 \%$ & $0 \%$ \\
\hline
\end{tabular}

Source: Elaborated by the authors based on the data published by CNPq directory (2016)

\subsection{Scientific production indexed internationally by number of published documents}

The analysis of the Brazilian bibliometric indicator published by SCImago Journal \& Country Rank portal, based on Scorpus database, involved the selection of four specific knowledge fields highly related to the biopharmaceutical activity: i) biochemistry, genetics and molecular biology; ii) immunology and microbiology; iii) medicine; iv) pharmacology, toxicology and pharmaceutical. The data reflects a growing number of Brazilian scientific publications internationally indexed and the increasing relevance of the Brazilian academic production in the international scenario.

For the set of Brazilian selected areas, the scientific production indexed internationally grew $277 \%$ from 2000 to 2014. The selected areas average annual growth rate between years 2000 and 2014 was

\footnotetext{
${ }^{9}$ Latest data available for the series.
} 
lower than the rate verified for Brazilian entire scientific output, reflecting a decreasing share of selected areas documents in Brazilian scientific output. Thus, the selected areas share in Brazilian scientific output decreased from 33\% in the year 2000 to $29 \%$ in the year 2014, as shown in table 4.

As for the World's scientific output in selected areas comparison, the share of Brazilian documents increased 111\% from 2000 to 2014. The data reflects an increasing relevance of the Brazilian academic production in the international scenario, thus national share in the worlds scientific production grew from $1.1 \%$ in 2000 to $2.3 \%$ in 2014 . Although it is recognized that these percentages are still limited, the Brazilian share in selected areas (2.3\%) discreetly surpasses the Brazilian shares in all areas $(2.2 \%)$.

Table 4 - Brazilian bibliometric indicators by number of documents (2000-2014)

\begin{tabular}{|c|c|c|c|c|c|c|c|c|}
\hline Subject area & 2000 & 2005 & 2010 & 2014 & $\begin{array}{l}\text { Average } \\
\text { share in } \\
\text { Brazil \% }\end{array}$ & $\begin{array}{r}\text { Average } \\
\text { share in } \\
\text { world } \\
\text { selected } \\
\text { areas } \%\end{array}$ & $\begin{array}{l}\text { Average } \\
\text { annual } \\
\text { growth } \\
2000- \\
2014 \%\end{array}$ & $\begin{array}{l}\text { Total growth } \\
2000-2014 \%\end{array}$ \\
\hline $\begin{array}{l}\text { Biochemistry, genetics and } \\
\text { molecular biology }\end{array}$ & 1.989 & 3.075 & 4.996 & 6.934 & $7.46 \%$ & $0.42 \%$ & $9.48 \%$ & $248.62 \%$ \\
\hline Immunology and microbiology & 840 & 1.397 & 2.079 & 2.675 & $3.16 \%$ & $0.18 \%$ & $8.79 \%$ & $218.45 \%$ \\
\hline Medicine & 4.005 & 7.356 & 14.266 & 16.578 & $18.04 \%$ & $1.06 \%$ & $11.01 \%$ & $313.93 \%$ \\
\hline $\begin{array}{l}\text { Pharmacology, toxicology and } \\
\text { pharmaceutics }\end{array}$ & 717 & 1.269 & 1.802 & 2.281 & $2.76 \%$ & $0.16 \%$ & $8.85 \%$ & $218.13 \%$ \\
\hline Brazil selected areas & 7.551 & 13.097 & 23.143 & 28.468 & $31.43 \%$ & $1.82 \%$ & $10.14 \%$ & $277.01 \%$ \\
\hline Brazil all areas & 22950 & 41307 & 76326 & 96680 & $100.00 \%$ & & $10.97 \%$ & $321.26 \%$ \\
\hline World selected areas & 702.999 & 848.495 & 1.064 .660 & 1.258 .151 & & & $4.26 \%$ & $78.97 \%$ \\
\hline World all areas & 2056078 & 2953848 & 3828739 & 4348858 & & & $5.54 \%$ & $111.51 \%$ \\
\hline $\begin{array}{l}\% \text { Brazil selected areas/ } \\
\text { Brazil all areas }\end{array}$ & $33 \%$ & $32 \%$ & $30 \%$ & $29 \%$ & & & & \\
\hline $\begin{array}{l}\% \text { Brazil selected areas/ } \\
\text { world selected areas }\end{array}$ & $1.1 \%$ & $1.5 \%$ & $2.2 \%$ & $2.3 \%$ & & & & \\
\hline $\begin{array}{l}\% \text { Brazil all areas/ } \\
\text { world all areas }\end{array}$ & $1.1 \%$ & $1.4 \%$ & $2.0 \%$ & $2.2 \%$ & & & & \\
\hline
\end{tabular}

Source: Elaborated by the authors based on bibliometric indicators database of the SCImago Journal \& Country Rank portal (based on Scopus ${ }^{\circ}$ database (Elsevier B.V. 2016)

SCImago Journal \& Country Rank data on number of international scientific publications allows a comparative analysis between countries in critical areas of knowledge. Graphic 1 shows the evolution in terms of scientific published documents in combined critical areas for the period of time between the years 2000 and 2014. The set of countries chosen for the comparison were United States, Germany, United Kingdom, China, India, Brazil, Russia and South Africa. The selection is not random: the first three countries are currently world leaders in the pharmaceutical and biotechnological industry, while the last five countries represent the political cooperation group entitled BRICS, a group of emerging countries with compatible level of development to Brazil.

Graphic 1 shows that the United States holds the isolated leadership in terms of scientific publications in selected areas, with 318.658 documents published in 2014 and an average growth rate of $3.42 \%$ from 2000 to 2014. Germany and the United Kingdom follow the United States, with 47.013 and 40.918 documents in 2014, respectively. Despite limited average growth rates for scientific output in selected areas, Germany $(2.76 \%)$ and the United Kingdom $(2,15 \%)$ are world leaders and serve as a great reference to Brazil.

When analyzing the BRICS evolutions, China is a major highlight. The country not only exceeded the number of documents of Germany and United Kingdom with its 145.221 publications in 2014, but also held an outstanding 21.31\% average growth for the 2000-2014 period. In 2014 China represented approximately $46 \%$ of United States publications for the same year, exceeding Brazil in both number of documents and growth rates. India is another BRIC partner that surpasses Brazil with its 52.070 published documents in 2014 and 12.67\% average growth rate. Despite being the third country ranked among BRICs, Brazil's performance is far from being negligible. The country exhibit 28.468 internationally indexed publications in critical areas for the year 2014 and grew at a $10.14 \%$ average rate during the period 2000-2014. Compared to Brazil, Russia has been overlapped in both number of documents in 2014 (15.898) and average growth (2.05\%). South Africa is the last ranked BRIC country, despite its $7.76 \%$ 
average annual growth rate between years 2000-2014, the country's total number of publications in 2014 was equal to 3.686 (equivalent to $13 \%$ of Brazil's publications in the same year).

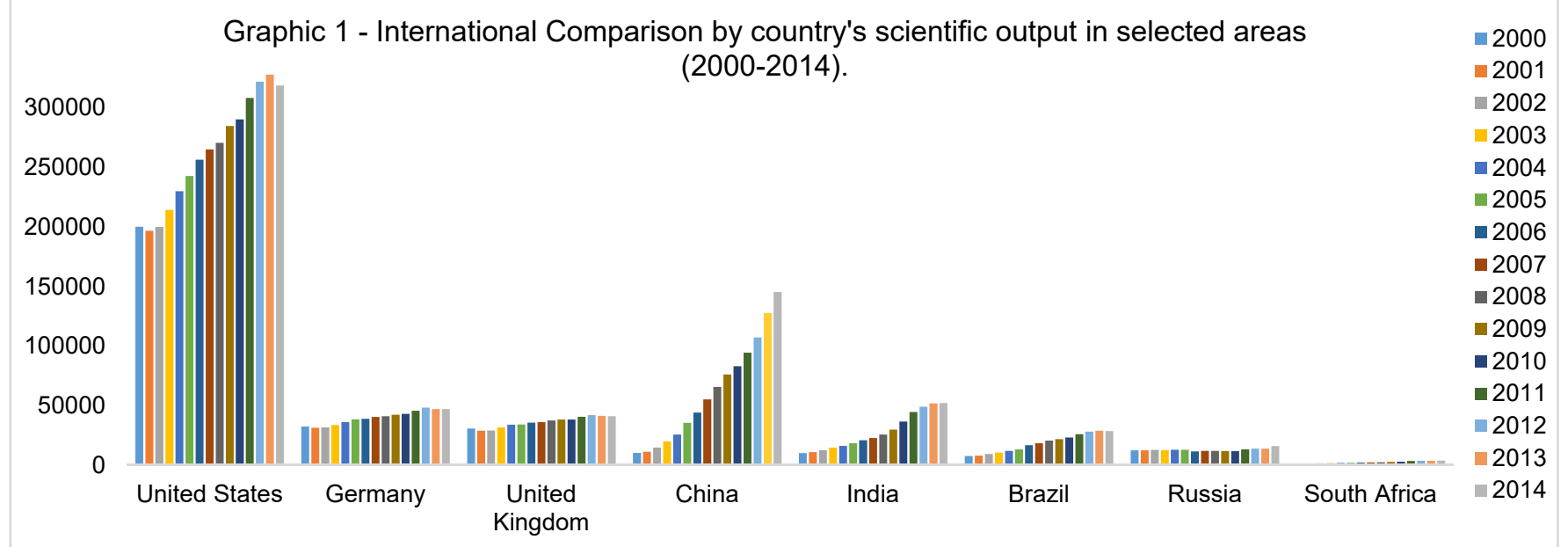

Source: Elaborated by the authors based on bibliometric indicators database of the SCImago Journal \& Country Rank portal (based on Scopus $®$ database (Elsevier B.V. 2016)

Another possible way to evaluate Brazilian international insertion is to compare it to neighboring countries. The set of countries chosen for the comparison were: Latin and Central America countries ${ }^{10}$ and Mercosur ${ }^{11}$ partnering countries. The data shows that Brazil internationally indexed publications represented approximately $67 \%$ of the 42.534 scientific documents in curtail areas published in whole Latin and Central America in 2014 and $86 \%$ of the 33.147 scientific documents published by all the Mercosur countries combined. Both Latin and Central America (8.75\%) and Mercosur (8.73\%) average annual growth rates in publications also seem to be led by the Brazilian average growth rate (10.14\%). The average share of Brazilian documents in these regions are $71 \%$ for Latin and Central America and $80.5 \%$ for Mercosur.

An alternative and more accurate way to evaluate Brazil's international insertion in terms of scientific output is to consider country rankings ordered by $\mathrm{H}$ index. The $\mathrm{H}$ index is a metric indicator that considers not only the number of scientific documents published by each county but also the number of citations each document received as a proxy to science impact in the international scientific community. The data collected from SCImago Journal \& Country Rank Portal concerning the period 1996-2015 and the countries: United States, Germany, United Kingdom, China, India, Brazil, Russia, South Africa, Argentina, Paraguay, Uruguay and Venezuela are displayed in table 5. The rankings showed at the table represent the international position of each country in comparison to the 239 countries present in the database. The data seams to corroborate in a great deal the county relative positions as shown in graphic 1.

\begin{tabular}{|c|c|c|c|c|c|c|c|c|c|c|c|}
\hline \multicolumn{3}{|c|}{$\begin{array}{l}\text { Biochemistry, Genetics and } \\
\text { Molecular Biology }\end{array}$} & \multicolumn{3}{|c|}{ Immunology and Microbiology } & \multicolumn{3}{|c|}{ Medicine } & \multicolumn{3}{|c|}{$\begin{array}{c}\text { Pharmacology, Toxicology and } \\
\text { Pharmaceutics }\end{array}$} \\
\hline Country & Rank & $\begin{array}{r}\mathrm{H} \\
\text { index }\end{array}$ & Country & Rank & $\begin{array}{r}\mathrm{H} \\
\text { index }\end{array}$ & Country & Rank & $\begin{array}{r}\mathrm{H} \\
\text { index }\end{array}$ & Country & Rank & $\begin{array}{r}\mathrm{H} \\
\text { index }\end{array}$ \\
\hline United States & 1 & 1077 & United States & 1 & 668 & United States & 1 & 1213 & United States & 1 & 486 \\
\hline United Kingdom & 2 & 666 & United Kingdom & 2 & 412 & United Kingdom & 2 & 806 & United Kingdom & 2 & 319 \\
\hline Germany & 3 & 601 & Germany & 3 & 407 & Germany & 4 & 672 & Germany & 3 & 270 \\
\hline China & 16 & 326 & China & 19 & 170 & Brazil & 19 & 306 & India & 12 & 181 \\
\hline India & 22 & 234 & Brazil & 22 & 147 & China & 20 & 306 & China & 15 & 165 \\
\hline Russia & 25 & 225 & India & 23 & 146 & India & 28 & 242 & Brazil & 20 & 131 \\
\hline Brazil & 29 & 209 & South Africa & 24 & 145 & South Africa & 29 & 239 & South Africa & 33 & 98 \\
\hline
\end{tabular}

${ }^{10}$ Includes: Brazil, Mexico, Argentina, Chile, Colombia, Venezuela, Cuba, Peru, Puerto Rico, Uruguay, Costa Rica, Ecuador, Panama, Trinidad and Tobago, Jamaica, Bolivia, Guatemala, Saint Kitts and Nevis, Honduras, Grenada, French Guiana, Barbados, Paraguay, Guadeloupe, Nicaragua, El Salvador, Dominican Republic, Haiti, Martinique, Bermuda, Guyana, Belize, Suriname, Dominica, Netherlands Antilles, Bahamas, Falkland Island, Cayman Island, Virgin Islands, Saint Vincent and the Grenadines, Anguilla, South Georgia and the South Sandwich Islands, Turks and Caicos Islands, Aruba, Montserrat, Saint Lucia, Antigua and Barbuda.

${ }^{11}$ Brazil, Argentina, Paraguay, Uruguay and Venezuela. 


\begin{tabular}{|c|c|c|c|c|c|c|c|c|c|c|}
\hline Argentina & 36 & 170 & Russia & 29 & 126 & Argentina & 33 & 225 & Russia & 39 \\
\hline South Africa & 37 & 162 & Argentina & 34 & 119 & Russia & 36 & 209 & Argentina & 40 \\
\hline Uruguay & 55 & 92 & Venezuela & 49 & 69 & Venezuela & 51 & 120 & Venezuela & 51 \\
\hline Venezuela & 58 & 86 & Uruguay & 75 & 56 & Uruguay & 69 & 96 & Uruguay & 61 \\
\hline
\end{tabular}

Source: Elaborated by the authors based on bibliometric indicators of SCImago Journal \& Country Rank portal database (based on Scopus ${ }^{\circledR}$ database (Elsevier B.V.)

The bibliometric indicators point to the fact that despite the lag in number of publications verified in the comparison between Brazil and world leaders in scientific publications in knowledge areas closely related to biopharmaceuticals RD\&I chain activities; Brazil exhibits a great potential to achieve a competitiveness in biopharmaceuticals science output. However, China's and India's high average growth rates point to the existence of a window of opportunity in the selected knowledge areas that Brazil is ceasing to appropriate. Concerning the regional sphere, Brazil is a unique regional partner with capabilities in scientific publications measured by number of documents that corresponds to the majority of both: Mercosur and Latin America scientific output.

\section{Collaborative relationships between research groups and the business sector}

The transfer of knowledge between academic and productive spheres is of particularly importance in the case of pharmaceutical and biotechnology firms dedicated to human health due to number of reasons. Firstly, the spillovers enable the development of products and services that are adequate to attend the specific phytosanitary standard requirements in Brazil. Secondly, the strengthening of collaborative relationships is key to promoting activities increasingly integrated to Brazil's Health Care Industrial Complex (CEIS) and to enable the development of technical and production capabilities in strategic areas. Finally, amassing capabilities to a standard of excellence in certain biological and health science areas can be a driver for strengthening innovation capabilities, provided they are aligned with the productive sector so that new products and processes can be developed (Britto et al, 2012)

In order to evaluate the intensity and the forms of interaction between research groups and pharmaceutical and biotechnological firms, an analysis of the $\mathrm{CNPq}$ directory statistics on interactions between research groups and the business sector in selected areas was held. It is important to remark that the information regarding university-industry interactions can suffer a double counting issue, as both groups and companies may relate or be related in up to three types of relationships. The elements are computed as many times as mentioned. Even recognizing the data limitation, the information is considered highly relevant so that relationship standards can be set and the dynamism of the joints in different areas related to the construction of competences for the biopharmaceutical industry innovation can be identified.

According to Table 6 , the number of research groups that reported active relationships with the productive sector grew 935\% from the year 2002 to 2014, overlapping in great amount the $631 \%$ growth rate experienced by $\mathrm{CNPq}$ total interactions. The expressive growth has been led by a high average growth in all knowledge areas. The proportion of selected areas in CNPq collaborative groups grew from $11.8 \%$ in 2002 to $16.7 \%$ in 2014 . The average share of groups that related interactions compared to the total number of research groups in each subject areas was more significant for areas like General biology, Biomedical engineering, Immunology, Genetics, Pharmacology and Microbiology.

\begin{tabular}{|c|c|c|c|c|c|c|c|c|c|}
\hline Subject area & 2002 & 2006 & 2010 & 2014 & $\begin{array}{r}\% \text { Average } \\
\text { share in } \\
\text { selected } \\
\text { areas } \\
2002-2014\end{array}$ & $\begin{array}{r}\% \text { Average } \\
\text { growth } \\
2002-2014\end{array}$ & $\begin{array}{r}\% \text { Total } \\
\text { growth } \\
2002-2014\end{array}$ & $\begin{array}{r}\% \text { Share of } \\
\text { groups that } \\
\text { related } \\
\text { relationships in } \\
\text { total groups } \\
2014 .\end{array}$ & $\begin{array}{r}\% \text { Average } \\
\text { share of groups } \\
\text { that related } \\
\text { relationships in } \\
\text { total groups } \\
2002-2014 .\end{array}$ \\
\hline Biochemistry & 14 & 18 & 40 & 168 & $9 \%$ & $91 \%$ & $1100 \%$ & $30 \%$ & $12 \%$ \\
\hline Biomedical engineering & 6 & 16 & 26 & 51 & $6 \%$ & $72 \%$ & $856 \%$ & $52 \%$ & $20 \%$ \\
\hline Biophysics & 3 & 8 & 4 & 24 & $2 \%$ & $115 \%$ & $700 \%$ & $35 \%$ & $12 \%$ \\
\hline General Biology & 7 & 7 & 7 & 27 & $2 \%$ & $58 \%$ & $286 \%$ & $43 \%$ & $25 \%$ \\
\hline Genetics & 15 & 29 & 50 & 171 & $11 \%$ & $72 \%$ & $684 \%$ & $32 \%$ & $16 \%$ \\
\hline Immunology & 4 & 14 & 14 & 66 & $2 \%$ & $191 \%$ & $7200 \%$ & $37 \%$ & $17 \%$ \\
\hline Medicine & 42 & 94 & 132 & 453 & $3 \%$ & $161 \%$ & $1850 \%$ & $28 \%$ & $7 \%$ \\
\hline Microbiology & 19 & 33 & 40 & 149 & $13 \%$ & $53 \%$ & $539 \%$ & $41 \%$ & $15 \%$ \\
\hline Morphology & 1 & 3 & 11 & 73 & $30 \%$ & $79 \%$ & $979 \%$ & $35 \%$ & $12 \%$ \\
\hline Parasitology & 4 & 8 & 10 & 78 & $5 \%$ & $57 \%$ & $750 \%$ & $28 \%$ & $11 \%$ \\
\hline
\end{tabular}




\begin{tabular}{|c|c|c|c|c|c|c|c|c|c|}
\hline Pharmacology & 9 & 20 & 26 & 86 & $11 \%$ & $78 \%$ & $1040 \%$ & $41 \%$ & $16 \%$ \\
\hline Pharmacy & 23 & 39 & 55 & 147 & $2 \%$ & $178 \%$ & $1650 \%$ & $32 \%$ & $8 \%$ \\
\hline Physiology & 4 & 6 & 8 & 70 & $4 \%$ & $118 \%$ & $1550 \%$ & $40 \%$ & $11 \%$ \\
\hline Selected areas & 151 & 295 & 423 & 1.563 & $100 \%$ & $79 \%$ & $935 \%$ & $33 \%$ & $13 \%$ \\
\hline Selected areas/CNPq \% & $11.8 \%$ & $11.8 \%$ & $12.1 \%$ & $16.7 \%$ & & & & & \\
\hline
\end{tabular}

Source: Elaborated by the authors based on the data published by CNPq directory (2016)

The CNPq directory statistics referring to the census 2014 about the number of private companies involved in university-industry collaborative relationships was unavailable until the release date of the article. In the aim to contemplate this aspect of the university-industry analysis, the latest data available refers to census conducted in the year 2010 was considered, as shown in Table 7.

In the year 2010, the 423 groups that have taken part in university-industry interactions in selected areas stablished connections to 668 private companies. The subject areas with the major number of enterprises were: Medicine, Pharmacy, Biochemistry and Genetics. It is important to mark out the these are the same knowledge areas that were highlighted for having greater relative share in selected areas and in CNPQ for number of research group, research lines and researchers. The total growth rate of private enterprises in selected areas $(209 \%)$ exceeded the growth rate of private enterprises in the entire $\mathrm{CNPq}$ database (175\%).

A cautious analysis of the list of company names involved in university-industry relationships by knowledge areas released by the $\mathrm{CNPq}$ directory allowed the authors to reach estimated percentages for actual pharmaceutical and biotechnology firms dedicated to human health that had active relationships with research groups in crucial areas. The achievement of these percentages may be considered a relevant contribution to the literature in biopharmaceuticals studies in Brazil. The share of pharmaceuticals and biopharmaceuticals firms in total CNPQ interacting firms was of 23\%. The subject areas that accounted for the highest percentages of pharmaceuticals and biotechnology firms dedicated to health care were: Immunology (44\%), Biophysics (40\%), Physiology (38\%), Pharmacology (35\%) and Pharmacy (35\%).

A database issue was diagnosed during the assessment. The list of private company names that have been reported as partners in university-industry relationships contained not only private enterprises, but also some research institutes, government institutions and other universities. As the major objective of the authors was to estimate the number of enterprises directly involved in the pharmaceutical productive sector and modern biotechnological developments for human health, were excluded from this estimation: biotechnology firms that were not dedicated to human health, firms dedicated to phytotherapics and machinery and equipment firms. On the other hand, firms related to clinical trials, cell banks, laboratories closely related to RD \& I in biopharmaceuticals and genetic sequencing bioinformatics companies were included in the percentages due to their positive impact on competence building.

\begin{tabular}{|c|c|c|c|c|c|c|}
\hline Subject area & 2002 & 2006 & 2010 & $\begin{array}{l}\text { Average Growth 2002- } \\
2010 \%\end{array}$ & $\begin{array}{l}\text { Total Growth } \\
2002-2010 \%\end{array}$ & $\begin{array}{l}\text { Pharmaceuticals and } \\
\text { Biotechnology firms for human } \\
\text { health share } 2010 \%\end{array}$ \\
\hline Biochemistry & 17 & 35 & 95 & $60 \%$ & $459 \%$ & $29 \%$ \\
\hline Biomedical engineering & 14 & 25 & 55 & $43 \%$ & $293 \%$ & $4 \%$ \\
\hline Biophysics & 4 & 11 & 5 & $17 \%$ & $25 \%$ & $40 \%$ \\
\hline General biology & 9 & 8 & 13 & $11 \%$ & $44 \%$ & $15 \%$ \\
\hline Genetics & 28 & 59 & 89 & $36 \%$ & $218 \%$ & $20 \%$ \\
\hline Immunology & 6 & 16 & 18 & $38 \%$ & $200 \%$ & $44 \%$ \\
\hline Medicine & 43 & 101 & 163 & $44 \%$ & $279 \%$ & $23 \%$ \\
\hline Microbiology & 38 & 56 & 63 & $14 \%$ & $66 \%$ & $14 \%$ \\
\hline Morphology & 1 & 4 & 15 & $115 \%$ & $1400 \%$ & $20 \%$ \\
\hline Parasitology & 4 & 8 & 12 & $48 \%$ & $200 \%$ & $17 \%$ \\
\hline Pharmacology & 16 & 30 & 31 & $21 \%$ & $94 \%$ & $35 \%$ \\
\hline Pharmacy & 33 & 64 & 101 & $33 \%$ & $206 \%$ & $35 \%$ \\
\hline Physiology & 3 & 6 & 8 & $46 \%$ & $167 \%$ & $38 \%$ \\
\hline Selected areas & 216 & 423 & 668 & $34 \%$ & $209 \%$ & $23 \%$ \\
\hline CNPq all areas & 2.436 & 4.534 & 6.692 & $30 \%$ & $175 \%$ & $2 \%$ \\
\hline Selected areas/CNPQ \% & $8.9 \%$ & $9.3 \%$ & $10.0 \%$ & & & \\
\hline
\end{tabular}

The CNPq directory data also enables the analysis of the university-industry interactions sorted by type of relationship for the year 2010, as shown in table 8. For the year 2010, 1242 types of relationships between research groups and industrial sector partners were reported by the groups in critical areas, 
representing a percentage of $9.5 \%$ of total types of relationships reported in CNPq directory. The types of relationships that were more relevant for the critical areas by share in total types of relationships were: applied research or scientific research with regards to immediate use of the results; basic research or scientific research without regard to immediate use of the results and technology transfers.

\begin{tabular}{|c|c|c|c|c|c|}
\hline Type of relationships & $\begin{array}{r}\text { Relationships } \\
\text { in selected } \\
\text { Areas }\end{array}$ & $\begin{array}{r}\text { Relationships } \\
\text { in CNPQ all } \\
\text { areas }\end{array}$ & $\begin{array}{r}\text { Type of } \\
\text { relationship } \\
\text { /selected areas } \\
\text { total } \\
\text { relationships \% }\end{array}$ & $\begin{array}{r}\text { Selected area } \\
\text { type of } \\
\text { relationships/ } \\
\text { CNPq type of } \\
\text { relationships\% }\end{array}$ & $\begin{array}{r}\text { Selected area } \\
\text { type of } \\
\text { relationships } \\
/ C N P Q \text { total } \\
\text { relationships\% }\end{array}$ \\
\hline Basic research & 221 & 1995 & $18 \%$ & $11 \%$ & $1.7 \%$ \\
\hline Applied research & 399 & 3813 & $32 \%$ & $10 \%$ & $3.0 \%$ \\
\hline Non-routine engineering to partner & 18 & 421 & $1 \%$ & $4 \%$ & $0.1 \%$ \\
\hline Non-routine engineering to group & 11 & 172 & $1 \%$ & $6 \%$ & $0.1 \%$ \\
\hline Software development from partner to group & 8 & 140 & $1 \%$ & $6 \%$ & $0.1 \%$ \\
\hline Software development from group to partner & 8 & 286 & $1 \%$ & $3 \%$ & $0.1 \%$ \\
\hline Technology transfer from group to partner & 151 & 1817 & $12 \%$ & $8 \%$ & $1.2 \%$ \\
\hline Technology transfer from partner to group & 40 & 319 & $3 \%$ & $13 \%$ & $0.3 \%$ \\
\hline Technical consultancy & 66 & 978 & $5 \%$ & $7 \%$ & $0.5 \%$ \\
\hline Input supply from partner to group & 129 & 1031 & $10 \%$ & $13 \%$ & $1.0 \%$ \\
\hline Input supply from group to partner & 13 & 92 & $1 \%$ & $14 \%$ & $0.1 \%$ \\
\hline Human resources training - partner employees & 45 & 820 & $4 \%$ & $5 \%$ & $0.3 \%$ \\
\hline Human resources training - researchers & 46 & 279 & $4 \%$ & $16 \%$ & $0.4 \%$ \\
\hline Other types of relationships & 87 & 950 & $7 \%$ & $9 \%$ & $0.7 \%$ \\
\hline Total relationships & 1242 & 13113 & $100 \%$ & & $9.5 \%$ \\
\hline
\end{tabular}

Source: Elaborated by the authors based on the data published by CNPQ Directory (2016)

The efforts made to effectively transfer knowledge between the scientific and the industrial sectors are considered a major key factor to buster RD\&I in biopharmaceuticals. Based on the specialized academic literature ${ }^{12}$, it is important to highlight the relevance of joints efforts to conduct scientific research, technology spillovers and human resources training interactions between university research groups and partners in the productive sector.

Regarding scientific research, the efforts on joint conduction of basic research are important to expand the pool of knowledge in critical areas and promote the development of absorptive capacity in pharmaceutical and biotechnology firms. The efforts on joint scientific research with regards to immediate use of the results and technological spillovers between research groups and productive sector are key to encourage innovative processes and the creation of new companies in new technological areas ("spin-offs") in short e medium terms. When analyzing the CNPq directory, it is possible to observe that university - industry interactions related to basic research grew 110\% from the year 2002 to year 2010 . The average biannual growth was equal to a $22 \%$ rate for the same time period and the participation in CNPq basic research relationships grew from $8 \%$ to $11 \%$. Applied research relationships grew $157 \%$ from the year 2002 to year 2010 . The average biannual growth was equal to a $28 \%$ for the same time period and the participation in $\mathrm{CNPq}$ applied research relationships grew from $9 \%$ to $10 \%$. Thus, both the growth rate and the total number of relationships in the year 2010 favored scientific research with regards to immediate use of the results rather than scientific research without regards to immediate use of the results.

Technology transfer interactions are another highly effective way of knowledge spillover with potential short terms results in boosting innovative activities and the creation of spinoffs in new technology areas. Based on the $\mathrm{CNPq}$ directory dataset, technology transfer relationships combined grew $108 \%$ from the year 2002 to year 2010. The average biannual growth was equal to $22 \%$ for the same period of time and the participation in CNPq technology transfer combined relationships grew from $9 \%$ to $10 \%$.

Other relevant sets of relationships are general training of human resources in strategic scientific areas interactions and specialized technological services, which represent efficient forms of personnel qualification and tacit knowledge spillovers for promoting personal interactions among employees and academic researchers. With regard to human resources training, the total growth from the year 2002 to

12 See Price (1965), Henderson et al. (1998), Gibbons e Johnston (1974), Pavitt (1991), Klevorick et al. (1995) and Cohen e Levinthal (1990). 
2010 was of $153 \%$; the average biannual growth was $28 \%$ and the participation in CNPq same type of relationships grew from $7 \%$ to $8 \%$. Concerning technical consultancy indicators, the total 2002-2010 growth in this type of relationship was of $65 \%$ and the average biannual growth was equal to $17 \%$. The share in $\mathrm{CNPq}$ all areas technical consultancies decreased from $8 \%$ to $7 \%$. The slightly decrease in technical consultancy $\mathrm{CNPq}$ share is not considered a critical problem, thus it may be associated with the growth of the alternative forms university-industry relationships.

\section{CNPq investment expenditures distribution by knowledge areas}

A number of authors have highlighted the importance of health care research efforts in Brazil, which strongly rely on the support of funding agencies. Data obtained from the CNPq Investment Panel database, called Payment Data Mart, which consolidates expenditures data on scholarships stipends and research support from year 2001 to year 2015, were analyzed. The information available covers the total value invested per year by knowledge areas. Besides the thirteen critical areas selected for the $\mathrm{CNPq}$ directory analysis, five additional areas considered closely related to the biopharmaceutical industry were added: Biotechnology, Biomedicine, Technological innovation and development in biology, Technology and innovation and Medical and health technologies (Table 10).

The eighteen selected areas received approximately $\mathrm{R} \$ 435.8$ million in funding from $\mathrm{CNPq}$ in the year 2015 , accounting for nearly $18 \%$ of total CNPq research funding. The amount was minor than the R\$ 516.4 million received in the previous year. While between the years 2001 and $2014 \mathrm{CNPq}$ funding for critical areas grew on an annual average rate of $15.61 \%$, higher than the rate seen for its total research funding (13.93\%). The variation rate between 2014 and 2015 was of $-15.62 \%$, as for the variation rate for $\mathrm{CNPq}$ total research funding was equal to $-14.5 \%$. The considerable reduction in CNPq expenditures for recent years is due to changes in Brazil's economic environment and a reverse towards the reduction of public spendings. The potential negative results of the reduction on $\mathrm{CNPq}$ expenditures values are a major concern and the actual impacts on the scientific infrastructure over the years will depend on how long the reduction holds and is yet hard to predict.

\begin{tabular}{|c|c|c|c|c|c|c|c|c|}
\hline & 2001 & 2005 & 2010 & 2014 & 2015 & $\begin{array}{c}\text { Average } \\
\text { growth } \\
2001- \\
2014 \% \\
\end{array}$ & $\begin{array}{c}\text { Average } \\
\text { growth } \\
2001- \\
2015 \% \\
\end{array}$ & $\begin{array}{l}\text { Growth } \\
\text { rate } \\
2014- \\
2015 \% \\
\end{array}$ \\
\hline Biochemistry & 12528 & 23425 & 41336 & 53210 & 44989 & $12 \%$ & $10 \%$ & $-15 \%$ \\
\hline Biomedical Engineering & 1707 & 4119 & 6589 & 18208 & 13994 & $22 \%$ & $19 \%$ & $-23 \%$ \\
\hline Biophysics & 4488 & 4721 & 8746 & 11546 & 11600 & $9 \%$ & $8 \%$ & $0 \%$ \\
\hline General biology & 2335 & 4802 & 7530 & 31712 & 19334 & $30 \%$ & $25 \%$ & $-39 \%$ \\
\hline Genetics & 10133 & 19955 & 38721 & 51642 & 41124 & $14 \%$ & $12 \%$ & $-20 \%$ \\
\hline Immunology & 4861 & 10531 & 19311 & 20794 & 19493 & $16 \%$ & $14 \%$ & $-6 \%$ \\
\hline Medicine & 15692 & 26714 & 69355 & 135663 & 115021 & $19 \%$ & $17 \%$ & $-15 \%$ \\
\hline Microbiology & 7749 & 10466 & 27699 & 33548 & 26289 & $14 \%$ & $11 \%$ & $-22 \%$ \\
\hline Morphology & 3063 & 5111 & 11546 & 20589 & 16443 & $16 \%$ & $14 \%$ & $-20 \%$ \\
\hline Parasitology & 4086 & 5890 & 15421 & 18528 & 16879 & $15 \%$ & $13 \%$ & $-9 \%$ \\
\hline Pharmacology & 9028 & 11201 & 19940 & 31875 & 30356 & $12 \%$ & $11 \%$ & $-5 \%$ \\
\hline Pharmacy & 4940 & 6873 & 20419 & 40367 & 32718 & $18 \%$ & $16 \%$ & $-19 \%$ \\
\hline Physiology & 5594 & 8457 & 20286 & 30462 & 27290 & $15 \%$ & $13 \%$ & $-10 \%$ \\
\hline Biotechnology & & 159 & 7090 & 1779 & 2164 & $205 \%$ & $188 \%$ & $22 \%$ \\
\hline Biomedicine & & 112 & 1581 & 1344 & 2696 & $72 \%$ & $74 \%$ & $101 \%$ \\
\hline \multicolumn{9}{|l|}{ Technological Innovation and } \\
\hline Development in Biology & & & 246 & 13523 & 14074 & $594 \%$ & $520 \%$ & $4 \%$ \\
\hline Technology and innovation & & & 11577 & 383 & 154 & $17 \%$ & $9 \%$ & $-60 \%$ \\
\hline Medical and health technologies & & & 580 & 1242 & 1155 & $71 \%$ & $56 \%$ & $-7 \%$ \\
\hline Selected areas & 86204 & 142536 & 327973 & 516415 & 435773 & $15.61 \%$ & $13.38 \%$ & $-15.62 \%$ \\
\hline CNPQ & 551815 & 827717 & 1586657 & 2781997 & 2382678 & $13.93 \%$ & $11.91 \%$ & $-14.35 \%$ \\
\hline$\%$ Selected areas/CNPQ & $16 \%$ & $17 \%$ & $21 \%$ & $19 \%$ & $18 \%$ & & & \\
\hline
\end{tabular}

Source: Elaborated by the authors based on the data published by CNPq Investiments Panel (2016)

An indicator was created by dividing the total funding in value allocated by CNPq in critical areas, gathered from $\mathrm{CNPq}$ Investments Panel database, by the number of research groups in selected areas, as obtained from the CNPq Research Groups Directory. Due to the mismatches in the two different databases, the compatibles areas selected were: Biochemistry, Biomedical engineering, Biophysics, 
General biology, Genetics, Immunology, Medicine, Microbiology, Morphology, Parasitology, Pharmacology, Pharmacy and Physiology. The investment expenditures per group indicator allows the comparison between the allocation of financial resources among critical knowledge areas for the period 2002-2010 $0^{13}$, as shown in Table 9.

Investment per group in selected areas total growth from year 2000 to 2014 was of $313 \%$ and the average growth was of 33\%. The Knowledge areas that received the highest proportions of incentives per group were: Pharmacology (24\%), General biology (14\%), Biophysics (10\%), Biochemistry (9\%) and Genetics (9\%). The average growth in investments per group were higher in General biology $(83 \%)$, Biomedical engineering (42\%), Medicine (40\%), Morphology (35\%), Parasitology (32\%) and Pharmacy (30\%). Unfortunately, it is not possible to identify correlations by comparing the areas highlighted for greater number of research groups and the areas marked out for receiving major incentives in terms of investment by research group. Further information may be needed to on go the correlations patterns comparison.

\begin{tabular}{|c|c|c|c|c|c|c|c|}
\hline Subject Area & 2002 & 2006 & 2010 & 2014 & $\begin{array}{r}\text { Average share on } \\
\text { expenditures \% }\end{array}$ & $\begin{array}{r}\text { Average growth } \\
2002-2014 \%\end{array}$ & $\begin{array}{r}\text { Total growth } \\
2002-2014 \%\end{array}$ \\
\hline Biochemistry & 47.1 & 74.0 & 108.5 & 112.0 & $9 \%$ & $19 \%$ & $138 \%$ \\
\hline Biomedical engineering & 30.5 & 59.7 & 78.4 & 154.3 & $7 \%$ & $42 \%$ & $405 \%$ \\
\hline Biophysics & 57.5 & 79.4 & 118.2 & 144.3 & $10 \%$ & $20 \%$ & $151 \%$ \\
\hline General biology & 40.8 & 51.3 & 228.2 & 609.8 & $14 \%$ & $83 \%$ & $1396 \%$ \\
\hline Genetics & 45.4 & 72.2 & 103.0 & 123.8 & $9 \%$ & $23 \%$ & $173 \%$ \\
\hline Immunology & 36.3 & 71.7 & 118.5 & 111.8 & $8 \%$ & $27 \%$ & $208 \%$ \\
\hline Medicine & 17.7 & 26.3 & 48.3 & 83.5 & $4 \%$ & $40 \%$ & $371 \%$ \\
\hline Microbiology & 34.4 & 40.3 & 92.3 & 91.9 & $6 \%$ & $25 \%$ & $167 \%$ \\
\hline Morphology & 20.8 & 39.1 & 57.7 & 91.1 & $5 \%$ & $35 \%$ & $338 \%$ \\
\hline Parasitology & 26.0 & 41.6 & 90.2 & 96.0 & $6 \%$ & $32 \%$ & $269 \%$ \\
\hline Pharmacology & 52.5 & 102.3 & 112.0 & 138.0 & $10 \%$ & $24 \%$ & $163 \%$ \\
\hline Pharmacy & 30.1 & 31.0 & 53.0 & 86.8 & $5 \%$ & $30 \%$ & $188 \%$ \\
\hline Physiology & 36.3 & 59.8 & 103.5 & 121.8 & $8 \%$ & $28 \%$ & $236 \%$ \\
\hline Total & 475.4 & 748.8 & 1311.8 & 1965.3 & $100 \%$ & $33 \%$ & $313 \%$ \\
\hline
\end{tabular}

\section{Main findings}

The scientific and technological infrastructure analysis held in this article allows the discussion of some important points to innovation and competence building in Brazilian biopharmaceuticals industry. First of all, the significant growth in the number of research groups, research lines and researchers dedicated to knowledge fields closely related to biopharmaceuticals industry points towards a strengthening trajectory concerning science and technological competences. The growing and strengthening trajectory is reinforced by the improving composition of research groups human resources, regarding the increase in researchers granted $\mathrm{MSc}$ or $\mathrm{PhD}$ degrees and the notable substitution effect favoring the higher specialized professionals. However, the CNPq directory data analyzed also marks a loss in the relative importance share of selected areas compared to Brazilian scientific production capacity evolution. That is to say that the research groups, research lines and researchers dedicated to other knowledge areas have grown on a more accelerated basis than the areas related to biopharmaceuticals; which evidences the fragility of the competence building process in science and technology that is been carried away in Brazil in recent years.

Despite the decrease in national share of scientific output, SCImago Journal \& Country Rank data points to a growing number of Brazilian scientific publications internationally indexed and the increasing relevance of the Brazilian academic production in the international scenario. There is an undeniable lag between Brazil and world leaders in selected knowledge areas concerning scientific output measured by both number of scientific documents. The comparison between BRICs points to the fact that Brazil's 10.14\% average annual growth for 2000-2014 is far from being enough to project the country as a leader among BRICs. China's and India's scientific output in biopharmaceutical related areas have both grew on a higher pace and achieved a greater amounts of published documents; which points to the fact

\footnotetext{
${ }^{13}$ According to the compatible data available from two different data sources: CNPQ Research Groups directory and CNPq Investiment panel (2016).
} 
that Brazil is falling behind in terms of benefitting from the window of opportunity opened in biopharmaceutical related knowledge fields. On the other hand, Brazil is the third BRIC country ranked by number of documents, exceeding Russia and South Africa. As for the regional sphere, Brazil is a unique regional partner with competences in scientific publications measured by number of documents. The county accounts for $71 \%$ average of the whole Latin and Central America scientific output and $80.5 \%$ of Mercosur countries output combined.

The mismatch between the production of knowledge in universities and innovation processes conducted in the productive sector has been highlighted in previous studies ${ }^{14}$ as a major Brazilian bottleneck to fostering biopharmaceutical RD \& I chain activities. One of the most positive traits verified through the $\mathrm{CNPq}$ data analysis held in this article is the expressive growth in relationships between research groups and enterprises. The number of research groups that reported active relationships with the productive sector grew 935\% from the year 2002 to 2014 and the number of enterprises related in the interactions grew 209\% from 2002 to 2010, both growth rates are higher than the ones verified for the $\mathrm{CNPq}$ areas. Unfortunately, the CNPq directory statistics referring to the census 2014 about the number of private companies involved in university-industry collaborative relationships was unavailable until the release date of the article.

On the one hand, allied to the significant growth in the number of research groups and private company's collaborative joints, there is an improvement in terms of types of relationships stablished. Applied research; basic research; direct technology transfers and Input supply were the most relevant forms of university-industry interactions in selected knowledge areas. From the year 2002 to the year 2010 , it is observed a significant growth in forms of relationships that are directly linked to knowledge flows and technology spillovers, such as: Applied research (157\%), basic research (110\%), technology transfer relationships (108\%) and human resources training relationships (153\%). The escalation of university-industry interactions is expected to foster innovation in Brazilian pharmaceutical and biopharmaceutical industry.

On the other hand, the limitations associated to research groups and productive sector articulations in order to promote innovation in biopharmaceuticals are brought to light by a simple comparison: while the critical knowledge areas accounted for $31.43 \%$ of Brazilian scientific output internationally indexed (2001-2014) and for 16\% of CNPq research groups (2000-2014); the corresponding percentages for interactive groups was $12.8 \%$ of CNPQ iterative groups (2002-2014) and 9.4\% of enterprises related to university-industry collaborative joints listed on $\mathrm{CNPq}$ directory. The mismatches between these percentages reinforce the argument of an existing gap between the knowledge advances in academia and the ability to spillover this knowledge over to the productive sector in order to foster the development of new marketable products and services related to the biopharmaceutical industry.

The assessment held in the list of company names involved in university-industry relationships in selected areas tends to confirm the existence of a major bottleneck regarding knowledge flows and technology transfers, despite the growing tendency in university-industry relationships. Only $23 \%$ of the companies involved in relationships in selected areas groups were actually associated with pharmaceuticals and biotechnology for human health activities. That is to say that only $2.3 \%$ enterprises listed in the CNPQ directory in the year 2010 were related to biopharmaceuticals activities. The knowledge areas that accounted for the highest percentages of pharmaceuticals and biotechnology firms dedicated to human health were: Immunology, Biophysics, Physiology, Pharmacology, Pharmacy, Biochemistry, Medicine and Genetics.

Finally, a major concern regarding the Brazilian growing but fragile science and technology infrastructure is the recent reduction in CNPq expenditures on research support and scholar stipends. The research efforts on pharmaceuticals and biotechnology related knowledge areas in Brazil strongly rely on the support of funding agencies, such as CNPq. While between the years 2001 and $2014 \mathrm{CNPq}$ funding for critical areas grew on an annual average rate of $15.61 \%$, the annual variation rate between 2014 and 2015 was of $-15.62 \%$. Not only have occurred an actual negative variation in expenses, but also the decrease in funding for 2014-2015 period for biopharmaceuticals related knowledge areas is more severe

\footnotetext{
${ }^{14}$ Guimarães (2004 and 2006) and Albuquerque and Souza (2004).
} 
than the average for $\mathrm{CNPq}$ all areas (-14.35\%). The considerable reduction in CNPq expenditures is due to changes in Brazil's economic environment and a reverse towards the reduction of public spending in public policy guidelines. It is hard to predict the actual negative impact that the cut in expenses may represent to the competence building process in biopharmaceuticals, however if it the reduction tendency holds for too long it may jeopardize the efforts that have been made to build these competences during the period 2000-2014.

\section{Conclusions}

The analysis presented in this paper showed that Brazil has a wide range of institutions with consolidated research groups in biology and health sciences and a growing and strengthening trajectory concerning the building of competences in biopharmaceuticals. The growing number of: research groups, research lines and researchers; Brazilian scientific publications internationally indexed and researchers granted $\mathrm{MSc}$ or $\mathrm{PhD}$ degrees are some of the result towards the scaling of the competence building process in academia regarding knowledge areas that are closely related to the biopharmaceutical RD \& I chain activities.

Concerning the insertion of the county in the international sphere, the results points to: 1) an existing lag between Brazil and world leaders in scientific output in knowledge areas closely related to biopharmaceuticals; 2) An opened window of opportunity in selected knowledge areas evidenced by China's and India's high average growth rates, that Brazil is falling behind in terms of benefitting from it; 3) Brazil is a unique regional partner that holds up a significant regional leverage among Latin and Central America countries.

However, there are also evidences that this infrastructure is still fragile and that progress in terms of building new capabilities in RD\&I are still limited in some crucial areas. Among these evidences, it is possible to mention the decrease in national share of scientific output internationally indexed; the relative loss of importance of the selected areas in the Brazilian overall scientific production capacity; the constraints to transfer knowledge to the productive sector and considerable decrease in public funding to support research activities in selected areas.

In this context, the transfer of knowledge generated in the scientific sphere to the productive sector becomes a key mechanism to foster innovation in the biopharmaceutical sector for a number of reasons. Firstly, the spillovers enable the development of products and services that are adequate to attend the specific phytosanitary standard requirements in Brazil. Secondly, the strengthening of collaborative relationships is key to promoting activities increasingly integrated to Brazil's Health Care Industrial Complex (CEIS). Finally, amassing capabilities to the academic sphere can be a driver for strengthening innovation capabilities, provided they are aligned with the productive sector so that new products and processes can be developed. The results point to a significant growth in university-industry relationships in selected areas and an improvement in terms of the types of relationships stablished. However, the existing gap between the knowledge advances in the academic environment and the correspondent low share of the private companies involved in university-industry collaborative joints are evidenced. Thus, it is important to continue and deepen the policies implemented in the sense of building a more solid and permanent bridges between companies, research institutions and the national health care system. Additionally, it is imperative to increase the number of actual pharmaceutical and biotechnology firms dedicated to human health involved in these relationships with research groups. However, the recent reduction on $\mathrm{CNPq}$ research support expenditures represents a threat to the competence building process described in this article in case it last for longer periods. 


\section{References}

ABDI. Incorporação da rota brasileira biotecnológica na indústria farmacêutica brasileira: desafios e oportunidades. In: Relatório de acompanhamento setorial. Maio de 2013.

ALBUQUERQUE EM, SOUZA SGA, Baessa AR. Pesquisa e inovação em saúde: uma discussão a partir da literatura sobre economia da tecnologia. Ciência e Saúde Coletiva. 2004;9(2):277-94.

ARORA, A. GAMBARDELLA, A. The division of innovative labor in biotechnology. In: ROSEMBERG, N. et al. Sources of Medical Technology: Universities and Industry. Washington, DC: National Academy Press p.188-208, 1995.

BIANCHI, C. "O papel das políticas públicas no regime de inovação de biotecnologia para saúde humana. Brasil 2002-2010”. Tese de Doutorado. Instituto de Economia, UFRJ. Rio de Janeiro. 2012.

BIOMINAS. PWC. A indústria de biociências nacional: caminhos para o crescimento. Belo Horizonte, 2011.

BRITTO, J.; VARGAS, M.A.; GADELHA, C.A.G. and COSTA, L.S. Health-related scientific and technological capabilities and university-industry research collaboration. Rev. Saúde Pública [online]. 2012, vol.46, suppl.1, pp.41-50.

CEBRAP. BRBIOTEC. Brazil Biotech Map 2011. São Paulo. 2011.

CNPq - Conselho Nacional de Desenvolvimento Científico e Tecnológico. Diretório Nacional dos Grupos de Pesquisa. Retrieved May 5, 2016, from: < http://lattes.cnpq.br/web/dgp/home>

CNPq - Conselho Nacional de Desenvolvimento Científico e Tecnológico. Painel de Investimentos. Retrieved May 5, 2016, from: $<$ http://cnpq.br/painel-de-investimentos $>$.

COHEN, W. LEVINTHAL, D. A. Absorptive capacity: A new perspective on learning and innovation. In: Administrative Science Quarterly, 1990, v. 35, pp. 128-153.

CORIAT, B. ORSI, F. WEINSTEIN, O. Does Biotech Reflect a New Science-based Innovation Regime?. In: Industry \& Innovation, v.10, p. 231 - 253. 2003.

DOSI, G. MAZZUCATO, M. Knowledge Accumulation and industry evolution. The case of PharmaBiotech. Cambridge University Press, P.1-19. 2006.

ELIASSON, G. ELIASSON, A. The Biotechnology Block of Competences. In: Revue de Economie Industrielle, v.2, p. 7 - 26. 1996.

FONSECA, M.G. Documento Setorial: Biotecnologia. In BNDES, UFRJ, UNICAMP orgs: Projeto Perspectivas do Investimento no Brasil. Rio de Janeiro. 2009.

GADELHA, CAG; MALDONADO, JMSV; VARGAS, MA; BARBOSA, P \& COSTA, LS. A dinâmica do sistema produtivo da saúde: inovação e complexo econômico-industrial. Rio de Janeiro: Ed. Fiocruz, 2012a; 221p.

GADELHA, CAG; MALDONADO, JMSV; VARGAS, MA; BARBOSA, P. (2012). O Complexo Econômico-Industrial da Saúde no Brasil: formas de articulação e implicações para o SNI em saúde. Revista Brasileira de Inovação, 2012b.

GEORGHIOU, L. Innovation, Learning and Macro-Institutional Change: the limits of the market model as an organizing principle for research systems. In Innovation, Science, and Industrial Change: $A$ research handbook, ed. Hage J and Meeus M, Oxford University Press. 2006

GIBBONS, M. e JOHNSTON, R. "The roles of science in technological innovation", Research Policy, 1974, v.3, 220-242.

GOMES, E., Clusters e biotecnologia para a superação da imitação: estudo de caso da indústria farmacêutica brasileira. Rio de Janeiro: PPED/IE/UFRJ. (Tese de Doutorado em Políticas Públicas, Estratégias e Desenvolvimento). 2014.

GUIMARÃES JA. A pesquisa médica e biomédica no Brasil: comparações com o desempenho científico brasileiro e mundial. Cienc Saude Coletiva. 2004;9(2):303-27.

GUIMARÃES R. Pesquisa em saúde no Brasil: contexto e desafios. Rev Saude Publica. 2006;40 N ${ }^{\circ}$ Espec:3-10. 
GUIMARÃES R. Desafios da pós-graduação em saúde humana no Brasil. Rev Saude Publica. 2011;45(1):1-13. DOI:10.1590/S0034-89102011000100001

GRAVAGLIA, C. et al. Entry, market structure and innovation in a "history friendly" model of the evolution of the pharmaceutical industry. In: DOSI, G. MAZZUCATO, M. orgs Knowledge Accumulation and industry evolution. The case of Pharma-Biotech. Cambridge University Press, P.1-19. 2006.

HENDERSON, R., JAFFE, A.B. y TRAJTENBERJ, M., (1998). "Universities as a source of commercial technology: a detailed analysis of university patenting 1965-1988". Review of Economics and Statistics, 1998, v.80, 119-127.

HETZKOWITZ, H. LEYDESDORFF, L. The dynamics of innovation: from National Systems of Innovation and Mode 2 to a Triple Helix of University-Industry-Government Relations. In: Policy Research, v.29, p. 109-23. 2000.

KLEVORICK, A.K., LEVIN, R.C., NELSON R.R. e WINTER, S.G., (1995). "On the sources and significance of interindustry differences in technological opportunities". Research Policy, 1995, v. 24, 185-205.

MAZZUCATO, M. The enterpreneurial state. Demos. Londres, 2011.

MOWERY, D. SAMPAT, B. Universities in National Inovations Systems". In FAGERBERG, J. et al. (orgs). The Handbook of innovation. Oxford University press, 2005.

MCKELVEY, M. ORSENIGO, L. Pharmaceuticals as a Sectoral Innovation System. In: ESSY Project. European Sectoral Systems of Innovation. 2001.

PARANHOS, Interação entre empresas e instituições de ciência e tecnologia: o caso do sistema farmacêutico de inovação brasileiro. Rio de Janeiro: Eduerj. 2012.

PAVITT, K. "What makes basic research economically useful?" Research Policy, 1991, V.20 (2), 109120.

PAVITT, K. Sectoral patterns of technical change: Towards a taxonomy and a theory. In: Research Policy v. 13, p. 343 - 372. 1984.

PRICE, D.S. "Is technology historically independent of science?" Technology and Culture, 1965, v.6, 553-568.

PUGATCH CONSILIUM "Building the Bioeconomy Examining National Biotechnology Industry Development Strategies", Report commissioned by the Biotechnology Industry Organization (BIO), 2014 SCImago (2014).SCJ - SCImago Journal \& Country Rank. Retrieved May 21, 2016, from $<$ http://www.scimagojr.com>

SEBRAE-SC - Serviço de Apoio às Micro e Pequenas empresas de Santa Catarina. Critérios de classificação de empresas: MEI - ME - EPP. Retrieved June 20, 2016, from: < http://www.sebraesc.com.br/leis/default.asp?vcdtexto=4154>

SHANE, S. Academic Enterpreunership. University Spinoffs and wealth creation. Edward Elgar Publishing Limited. Massachusetts, 2004.

VARGAS, M. A.; BRITTO, J. A systemic innovation policy with an inclusive perspective: the evolution of the Brazilian policy to the pharmaceutical sector. In: 3th Globelics International Conference, 2015, Havana, Cuba. 3th Globelics International Conference: Innovation to reduce poverty and inequalities for Inclusive and sustainable development, 2015.

VARGAS, M. A.; BRITTO, J. Innovation, and competence building in the pharmaceutical and biopharmaceutical industry in Brazil. In: 12th Globelics Conference - Partnerships for innovation-based development, 2014, Addis Ababa, Ethiopia. 12th Globelics Conference - Partnerships for innovationbased development, 2014.

VARGAS, M. A.; GADELHA, CAG.; MALDONADO, JMSV.; COSTA, L. (2012) Innovation in pharmaceutical and health biotechnology industries: challenges for a virtuous agenda. Revista de Saúde Pública, v. 46, 2012. p. 37-40

VARGAS, M. A; GADELHA, CAG.; MALDONADO, JMSV.; COSTA, L.; QUENTAL, C. Indústria de base química e biotecnologia voltadas para a saúde no Brasil: panorama atual e perspectiva para 2030. In: Fiocruz; Ipea, Ministério da Saúde; Secretaria de Assuntos Estratégicos da Presidência da República. (Org.). A saúde no Brasil em 2030: prospecção estratégica do sistema de saúde brasileiro: 
desenvolvimento produtivo e complexo da saúde. 22 ed.Rio de Janeiro: Editora Fiocruz, 2013, v. 05, p. 29-78. 